\title{
Comparison of late HIV diagnosis as a marker of care for Aboriginal versus non-Aboriginal people living with HIV in Ontario
}

\author{
Denise Jaworsky MD ${ }^{1}$, LaVerne Monette LLB ${ }^{2 *}$, Janet Raboud $\mathrm{PhD}^{3,4}$, Doe O'Brien-Teengs HBA MA ${ }^{2,5}$, \\ Christina Diong $\mathrm{MSc}^{3}$, Sandra Blitz $\mathrm{MSc}^{3}$, Sean B Rourke $\mathrm{PhD}^{6,7,8}$, Mona R Loutfy MD MPH ${ }^{1,9}$; \\ and the OHTN Cohort Study Team
}

D Jaworsky, LV Monette, J Raboud, et al; and the OHTN Cohort Study Team. Comparison of late HIV diagnosis as a marker of care for Aboriginal versus non-Aboriginal people living with HIV in Ontario. Can J Infect Dis Med Microbiol 2012;23(4):e96-e102.

BACKGROUND: Studies have found that Aboriginal people living with HIV/AIDS (APHAs) are more likely than non-APHAs to receive suboptimal HIV care, yet achieve similar clinical outcomes with proper care.

OBJECTIVE: To compare the proportions of individuals diagnosed late with HIV between APHAs and non-APHAs within the Ontario HIV Treatment Network Cohort Study (OCS).

METHODS: The analysis included OCS participants who completed the baseline visit by November 2009. Two definitions of the outcome of late HIV diagnosis were used: the proportion of participants with an AIDSdefining illness (ADI) before or within three months of HIV diagnosis; and the proportion of participants with a $\mathrm{CD}^{+}{ }^{+}$count $<200 \mathrm{cells} / \mathrm{mL}$ at diagnosis. Logistic regression analysis was used to assess the association between Aboriginal ethnicity and late HIV diagnosis.

RESULTS: APHAs were more likely to be female and have lower income, education and employment. No statistically significant differences were noted in the proportions receiving a late HIV diagnosis defined by ADI (Aboriginal 5.2\% versus non-Aboriginal 6.3\%; $\mathrm{P}=0.40$ ). Multivariate logistic regression analysis revealed a significant association between Aboriginal ethnicity and late HIV diagnosis defined by $\mathrm{CD}^{+}$count after adjusting for age and HIV risk factor (OR 1.55; P=0.04).

DISCUSSION: APHAs were more likely to have a $\mathrm{CD}^{+}$count $<200$ cells/mL at diagnosis but had similar clinical outcomes from late diagnosis when defined by ADI. However, differences may be underestimated due to recruitment limitations and selection bias.

CONCLUSION: Additional work is needed to address the socioeconomic and health care needs of APHAs.

Key Words: Aboriginal peoples; Access to care; Cohort study; HIV; HIV diagnosis; Quality of care

$\mathrm{D}_{\mathrm{p}}^{\mathrm{cos}}$ espite increases in HIV research and advances in care and support programs in Canada, the Aboriginal population remains both over-represented in the Canadian HIV epidemic and underrepresented in research. In 2006, 27.3\% of positive HIV test reports were attributable to Aboriginal peoples in Canadian provinces and territories that reported ethnicity data for HIV testing. In these provinces and territories, Aboriginal peoples represent $6.0 \%$ of the total population; therefore, Aboriginal people are over-represented by approximately 4.6 times in the HIV epidemic in Canada (1).

\section{La comparaison d'un diagnostic tardif de VIH comme marqueur des soins des Autochtones par rapport aux non-Autochtones qui vivent avec le VIH en Ontario}

HISTORIQUE : Les études ont démontré que les Autochtones qui vivent avec le VIH ou le sida (AVVS) sont plus susceptibles que les nonAutochtones qui vivent avec le VIH ou le sida (NAVVS) de recevoir des soins sous-optimaux, mais présentent des issues cliniques similaires lorsqu'ils reçoivent des soins convenables.

OBJECTIF : Comparer la proportion d'AVVS et de non-AVVS de la cohorte OCS du réseau thérapeutique du VIH qui reçoivent un diagnostic tardif de VIH de l'Ontario.

MÉTHODOLOGIE : L'analyse incluait les participants de l'OCS qui avaient eu leur première visite avant novembre 2009. Deux définitions de l'issue de diagnostic tardif du VIH ont été utilisées : la proportion de participants ayant une maladie symptomatique du sida (MSS) avant ou dans les trois mois suivant le diagnostic du VIH, et la proportion de participants ayant une numération de $\mathrm{CD}^{+}{ }^{+}$inférieure à 200 cellules $/ \mathrm{mL}$ au diagnostic. Les chercheurs ont utilisé l'analyse de régression logistique pour évaluer l'association entre l'ethnie autochtone et le diagnostic tardif de VIH.

RÉSULTATS : Les AVVS étaient plus susceptibles d'être des femmes et d'avoir un revenu et une scolarisation plus faibles ainsi qu'un emploi moins bien rémunéré. Les chercheurs n’ont perçu aucune différence statistiquement significative dans la proportion qui avait reçu un diagnostic tardif de VIH défini par une MSS (Autochtones 5,2 \%, non-Autochtones $6,3 \% ; \mathrm{P}=0,40)$. L'analyse de régression logistique multivariée a révélé une association significative entre l'ethnie autochtone et un diagnostic tardif de VIH défini par la numération de $\mathrm{CD}^{+}$après rajustement compte tenu de l'âge et du facteur de risque de VIH ( $R R R=1,55 ; \mathrm{P}=0,04)$.

EXPOSÉ : Les AVVS étaient plus susceptibles de présenter une numération de $\mathrm{CD}^{+}{ }^{+}$inférieure à 200 cellules $/ \mathrm{mL}$ au diagnostic, mais avaient des issues cliniques similaires de diagnostic tardif lorsqu'on le définissait par une MSS. Cependant, les différences sont peut-être sous-estimées en raison des limites de recrutement et du biais de sélection.

CONCLUSION : D'autres travaux s'imposent pour connaître les besoins socioéconomiques et en soins de santé des AVVS.

*Deceased

${ }^{1}$ Faculty of Medicine, University of Toronto; ${ }^{2}$ Ontario Aboriginal HIVIAIDS Strategy; ${ }^{3}$ University Health Network; ${ }^{4}$ Dalla Lana School of Public Health, University of Toronto, Toronto; ${ }^{5}$ Mushkego Cree, Weenusk First Nation, Ontario; ${ }^{6}$ Ontario HIV Treatment Network; ${ }^{7}$ Department of Psychiatry, University of Toronto; ${ }^{8}$ Keenan Research Centre in the Li Ka Shing Knowledge Institute, St Michael's Hospital; ${ }^{9}$ Women and HIV

Research Program, Women's College Research Institute, Toronto, Ontario

Correspondence: Dr Mona Loutfy, Women and HIV Research Program, Women's College Research Institute, 790 Bay Street, 7th Floor,

Suite 743, Toronto, Ontario M5G 1N8. Telephone 416-465-0856 ext 2444, fax 416-351-3746, e-mail mona.loutfy@wchospital.ca 
Limited access to primary health care services among Aboriginal populations in Ontario has been reported based on higher hospital admission rates for conditions that could effectively be managed in an ambulatory care setting when compared with the general population (4). For example, in Ontario, individuals from Aboriginal communities, rural communities and remote communities have been found to be diagnosed with diabetes at a later stage, and to be more likely to visit an emergency department or be admitted to hospital for diabetes management than individuals from urban and non-Aboriginal communities (5). Such a finding may apply to the HIV field, such that Aboriginal people may similarly experience a trend of late diagnosis for HIV. The high concentration of Canadian Aboriginal peoples in rural areas may also contribute to their limited access to health care. In 2004, 21.1\% of the Canadian population, but only $9.4 \%$ of Canadian physicians, were located in rural areas (6). Additional barriers to accessing health care among Aboriginal populations include perceived racism, differences in cultural beliefs and values, and a shortage of Aboriginal physicians (7). Nearly all of the Aboriginal people living with HIV/AIDS (APHAs) in Canada have either been directly subjected to or had a family member who was subjected to the residental school system. Accordingly, access to health care services and the trust placed in health care providers by Aboriginal peoples is profoundly impacted by historical factors and the repercussions of the residential school system (8).

Late diagnosis of HIV has important consequences for clinical outcomes as well as on health care costs. For example, late diagnosis of HIV (CD4 ${ }^{+}$count $<200$ cells $/ \mathrm{mL}$ ) is associated with higher mortality despite earlier initiation of therapy $(9,10)$. In Alberta, individuals diagnosed with HIV with a CD4 ${ }^{+}$count $<200$ cells/mL were found to incur medical care costs twice as high as those of patients diagnosed with a $\mathrm{CD}^{+}$count $>200$ cells $/ \mathrm{mL}$ in the year following diagnosis. In addition, HIV-related hospital care costs were 15 times higher for those diagnosed late (11). Furthermore, earlier HIV diagnosis creates opportunities to reduce the risk of subsequent transmissions by offering earlier treatment and thorough behavioural modifications $(12,13)$.

Several studies have identified predictors of late HIV diagnosis. In a Texan cohort, female sex and illicit drug use were associated with a higher $\mathrm{CD}^{+}$count at diagnosis, potentially from perceived increased risk in this population (14). In other studies, heterosexual contact and an absense of reported risk factors were often associated with late HIV diagnosis (15-17). In a study of 219 Aboriginal British Columbia residents, participants with an HIV risk factor, such as a previous positive test result for a sexually transmitted infection or needle sharing, were more likely to undergo HIV testing (18).

Factors such as cultural approriateness of services may influence the acceptance of HIV testing within a community. An exploratory, qualitative analysis of the experiences of seven Aboriginal Canadian women identified fear of unfair judgment as a barrier to HIV testing, and this was linked to a lack of familiarity with the context of the lives of Aboriginal women. In addition, these women perceived HIV testing to infringe on the cultural norm of not disclosing problems to noncommunity members (19).

In addition to being at risk for late diagnosis of HIV, Aboriginal peoples may receive poorer quality of care once an HIV diagnosis is established. A study conducted in northern Alberta found that Aboriginal ethnicity was associated with a longer median time to accessing care after HIV diagnosis (20). A study conducted in British Columbia found that Aboriginal peoples are more likely to receive double versus triple antiretroviral therapy (ART), to be less adherent in the first year of treatment and to have a physician less experienced in treating HIV compared with non-Aboriginal peoples. However, when controlling for these factors, Aboriginal peoples were found to have comparable virological response to ART (21). Accordingly, there is a need for additional information regarding ART use among Aboriginal peoples in Ontario. In addition, a cohort study of HIVpositive pregnant women in Ontario, Manitoba and Saskatchewan found that Aboriginal women were more likely to experience delayed start of ART when compared with other ethnicities (22).
In the present study, we investigated the difference in the proportion of individuals diagnosed late with HIV between APHAs and non-APHAs within the Ontario HIV Treatment Network Cohort Study (OCS).

Late diagnosis of HIV was defined in two ways: an AIDS-defining illness (ADI) before or within three months of their HIV diagnosis; and a CD4 ${ }^{+}$count $<200$ cells $/ \mathrm{mL}$ at diagnosis. Differences between female and male APHAs were also assessed.

\section{METHODS}

\section{Study population and design: OCS}

The OCS is a multisite, prospective, observational cohort of individuals living with HIV who, since 1997, have been recruited from primary and tertiary care sites throughout Ontario. Information is collected on demographics, HIV-related laboratory values, HIV- and AIDS-related illnesses, comorbidities, drug adverse events, HIV genotypes and sociobehavioural measures. Data are collected from multiple sources including electronic medical records, chart abstraction and linkages to other laboratory databases. Data are collected on each participant every six months.

For the present analysis, the inclusion criteria were: enrollment in the OCS; completed information on self-reported ethnicity; and completed data on date of HIV diagnosis. In the analysis of ADI before or within three months of HIV diagnosis, participants who did not have an ADI were excluded if their follow-up in the cohort was less than three months. The data included cross-sectional data from the baseline visit on participants who were enrolled until November 2009.

\section{Study predictors and outcomes}

One outcome of interest was an ADI before or within three months of the first HIV diagnosis. Another outcome was defined as a $\mathrm{CD}^{+}$ count $<200$ cells $/ \mathrm{mL}$ at the time of the first HIV diagnosis. Because $\mathrm{CD}^{+}$measurement is not routinely performed with HIV testing, the $\mathrm{CD}^{+}$count at diagnosis was defined as the first $\mathrm{CD}^{+}$count recorded within the first six months after HIV diagnosis. The primary and secondary outcomes were compared between Aboriginal and nonAboriginal participants, and between male and female Aboriginal participants.

Participants were classified as Aboriginal participants if they indicated Aboriginal ancestry in response to any of the following questions: How do you characterize your racial background?; If Canadian Aboriginal, to which Canadian Aboriginal group do you belong?; If First Nations, are you: status / non-status / don't know / refused?; To which ethnic or cultural group(s) did your ancestors belong?

\section{Statistical analysis}

Baseline demographic and clinical characteristics were tabulated according to ethnicity (Aboriginal versus non-Aboriginal) and sex for the Aboriginal population (male versus female). Categorical variables were summarized with frequencies and proportions and compared between groups using $\chi^{2}$ tests. Continuous variables were summarized with medians and interquartile ranges (IQR) and compared between groups using Wilcoxon rank sum tests. Logistic regression models were used to determine the association between Aboriginal ethnicity and late diagnosis. Separate analyses were conducted for each late HIV diagnosis outcome. Logistic regression models were also used to assess the association between sex and late diagnosis within the Aboriginal population. Data were analyzed using SAS statistical software version 9.2 (SAS Institute Inc, USA).

\section{Ethical considerations}

Written informed consent was obtained from all participants of the OCS. The present study was approved by the University of Toronto (Toronto, Ontario) Research Ethics Board and the OCS Governance Committee (the latter comprised of a majority of people living with HIV). Because the present study pertains to Aboriginal people in Canada, Ownership, Control, Access, and Possession (OCAP) principles were adhered to. 


\section{RESULTS}

As of November 2009, 5044 participants were enrolled in the OCS. Of these, 4862 had a known date of HIV diagnosis. Of participants with a known date of diagnosis, 350 were Aboriginal peoples, 4235 were non-Aboriginal peoples and 277 had missing ethnicity data. Twelve non-Aboriginal and one Aboriginal participant had follow-up of less than three months or incomplete information for both the time of diagnosis and onset of an ADI that were in the same year and, therefore, it was not possible to determine the timing of the ADI relative to HIV diagnosis. Accordingly, the analysis according to ADI included 349 Aboriginal and 4223 non-Aboriginal participants. The analysis of $\mathrm{CD}^{+}$count $<200$ cells $/ \mathrm{mL}$ at diagnosis included 114 Aboriginal and 1626 non-Aboriginal participants because $\mathrm{CD}^{+}$data at the time of HIV diagnosis were missing for all other participants.

\section{Baseline characteristics}

The demographic and clinical characteristics for APHAs versus nonAPHAs are summarized in Table 1. When compared with nonAboriginal participants, Aboriginal participants were younger, more likely to engage in IDU and heterosexual transmission as HIV risk factors, and were more likely to be living in northern Ontario. With regard to socioeconomic factors, Aboriginal participants were less likely to be employed, more likely to have a level of education less than a high school diploma and more likely to have a household annual income $<\$ 20,000$. Aboriginal participants were also more likely to be coinfected with hepatitis C.

Table 2 describes the demographic and clinical characteristics of Aboriginal participants according to sex (male versus female). Among Aboriginal participants, women were younger and more likely to live in northern Ontario. Women were more likely to have IDU and heterosexual transmission as HIV risk factors. Women were less likely to be employed, more likely to have a level of education less than a high school diploma and more likely to have a household annual income $<\$ 20,000$. In addition, female Aboriginal participants were more likely to be hepatitis $\mathrm{C}$ coinfected than male Aboriginal participants $(42 \%$ versus $24 \%[\mathrm{P}<0.01])$. Female Aboriginal participants were less likely to have ever been on ART ( $73 \%$ versus $89 \%[\mathrm{P}<0.01]$ ) and the Kaplan-Meier estimate for median duration from HIV diagnosis to ART initiation for female and male Aboriginal participants were 3.0 years (95\% CI 2.1 to 4.7 ) and 3.6 years (95\% CI 2.9 to 4.0 ), respectively $(\log \operatorname{rank} \mathrm{P}=0.73)$.

Analysis of ADI before or within three months of HIV diagnosis In the univariate analyses, the proportions of APHAs and non-APHAs who had an ADI before or within three months of their first HIV diagnosis were $5.2 \%$ and $6.3 \%$, respectively $(\mathrm{P}=0.40)$. After adjusting for age and HIV risk factor in the logistic regression model, Aboriginal ethnicity remained unassociated with late diagnosis of HIV as defined according to diagnosis of an ADI before or within three months of HIV diagnosis (OR 0.89 [95\% CI 0.54 to 1.47]; $\mathrm{P}=0.65$ ) (Table 3).

Analysis of $\mathrm{CD}^{+}$count $<200$ cells/mL at HIV diagnosis

There were more non-APHAs $(n=1626$ [38\%]) with available data on a $\mathrm{CD}^{+}{ }^{+}$count within six months of HIV diagnosis compared with APHAs $(n=114[33 \%])(P=0.03)$. The proportions of APHAs and nonAPHAs who had a CD4 ${ }^{+}$count $<200$ cells $/ \mathrm{mL}$ at the time of their HIV diagnosis were $35 \%$ and $29 \%$, respectively $(\mathrm{P}=0.18)$. Median $\mathrm{CD}^{+}$ counts at the time of HIV diagnosis for Aboriginal and non-Aboriginal participants were 299 cells/mL (IQR 111 cells $/ \mathrm{mL}$ to 520 cells $/ \mathrm{mL}$ ) and 341 cells $/ \mathrm{mL}$ (IQR 156 cells $/ \mathrm{mL}$ to 518 cells $/ \mathrm{mL}$ ), respectively $(\mathrm{P}=0.24)$. After adjusting for age and HIV risk factors in the logistic regression model, Aboriginal ethnicity was significantly associated with having a $\mathrm{CD}^{+}{ }^{+}$count $<200$ cells $/ \mathrm{mL}$ at the time of HIV diagnosis (OR 1.55 [95\% CI 1.03 to 2.35]; $\mathrm{P}=0.04$ ) (Table 3).

Analyses of Aboriginal population according to sex

Analyses were performed comparing proportions of Aboriginal participants receiving a late diagnosis of HIV according to sex. Fifty-nine
TABLE 1

Participant demographic and clinical characteristics according to Aboriginal ethnicity

\begin{tabular}{|c|c|c|c|}
\hline & $\begin{array}{l}\text { Aboriginal } \\
(n=350)\end{array}$ & $\begin{array}{l}\text { Non- } \\
\text { Aboriginal } \\
(n=4235)\end{array}$ & $\mathbf{P}$ \\
\hline $\begin{array}{l}\text { Age, years, } \\
\text { median (interquartile range ) }\end{array}$ & $\begin{array}{c}45.0 \\
(38.0-50.0)\end{array}$ & $\begin{array}{c}48.0 \\
(42.0-54.0)\end{array}$ & $<0.0001$ \\
\hline Male sex & $290(83)$ & $3692(87)$ & 0.02 \\
\hline Ever on antiretroviral treatment & $302(86)$ & $3784(89)$ & 0.07 \\
\hline AIDS defining illness & $116(33)$ & $1505(36)$ & 0.36 \\
\hline HIV risk factor & & & $<0.0001$ \\
\hline MSM & $175(50)$ & $2718(64)$ & \\
\hline IDU/MSM-IDU & $104(30)$ & $483(11)$ & \\
\hline Heterosexual transmission & $52(15)$ & $428(10)$ & \\
\hline From country with high HIV prevalence & $0(0)$ & $369(9)$ & \\
\hline Other & $19(5)$ & $237(6)$ & \\
\hline Geographical location in Ontario & & & $<0.0001$ \\
\hline Metropolitan Toronto & $123(38)$ & $2210(55)$ & \\
\hline Central & $36(11)$ & $498(13)$ & \\
\hline Eastern & $68(21)$ & $679(17)$ & \\
\hline Southwestern & $37(11)$ & $418(10)$ & \\
\hline Northern & $56(17)$ & $169(4)$ & \\
\hline Other & $<5(1)$ & $9(0)$ & \\
\hline Employment status & & & $<0.0001$ \\
\hline Employed full or part time & $93(34)$ & $1194(50)$ & \\
\hline Student & $6(2)$ & $62(3)$ & \\
\hline Retired & $15(6)$ & $198(8)$ & \\
\hline Disability & $121(45)$ & $739(31)$ & \\
\hline Unemployed & $35(13)$ & $210(9)$ & \\
\hline Missing data & $80(23)$ & $1832(43)$ & \\
\hline Highest education level & & & $<0.0001$ \\
\hline Some high school & $73(27)$ & $299(12)$ & \\
\hline Completed high school & $49(18)$ & $426(18)$ & \\
\hline Some college/university & $63(23)$ & $546(23)$ & \\
\hline Completed college/university & $70(26)$ & $908(38)$ & \\
\hline Postgraduate education & $16(6)$ & $233(10)$ & \\
\hline Missing data & $79(23)$ & $1823(43)$ & \\
\hline Marital status & & & 0.59 \\
\hline Married, living common-law & $104(38)$ & 947 (39) & \\
\hline Separated/divorced & $17(6)$ & $195(8)$ & \\
\hline Widowed & $9(3)$ & $60(2)$ & \\
\hline Single & $141(52)$ & $1205(50)$ & \\
\hline Missing data & $79(23)$ & $1828(43)$ & \\
\hline Household income/year, \$ & & & $<0.0001$ \\
\hline$<20,000$ & $104(43)$ & $568(26)$ & \\
\hline 20,000 to $<40,000$ & $41(17)$ & $462(21)$ & \\
\hline 40,000 to $<60,000$ & $28(12)$ & $334(15)$ & \\
\hline 60,000 to $<80,000$ & $24(10)$ & $249(11)$ & \\
\hline 80,000 to $<100,000$ & $20(8)$ & $183(8)$ & \\
\hline$\geq 100,000$ & $26(11)$ & 410 (19) & \\
\hline Missing data & $107(31)$ & $2029(48)$ & \\
\hline Hepatitis B coinfection & $32(9)$ & $449(11)$ & 0.40 \\
\hline Hepatitis C coinfection & $94(27)$ & $666(16)$ & $<0.0001$ \\
\hline
\end{tabular}

Data presented as $n(\%)$ unless otherwise indicated. IDU Injection drug use, MSM Men who have sex with men

female Aboriginal participants and 290 male Aboriginal participants were included in a comparison of the proportions of individuals who had an ADI before or within three months of their HIV diagnosis. Many participants were missing data on $\mathrm{CD}^{+}$counts, resulting in only 20 female Aboriginal participants and 94 male Aboriginal 
TABLE 2

Aboriginal participants' demographic and clinical characteristics according to sex

\begin{tabular}{|c|c|c|c|}
\hline & Male $(n=290)$ & Female $(n=60)$ & $\mathbf{P}$ \\
\hline $\begin{array}{l}\text { Age, years, median } \\
\text { (interquartile range) }\end{array}$ & $46.0(39.0-51.0)$ & $40.5(35.5-48.5)$ & $<0.01$ \\
\hline Ever on antiretroviral treatment & $258(89)$ & $44(73)$ & $<0.01$ \\
\hline AIDS-defining illness & $99(34)$ & $17(28)$ & 0.38 \\
\hline HIV risk factor & & & $<0.0001$ \\
\hline MSM & $175(60)$ & $0(0)$ & \\
\hline IDU/MSM-IDU & $78(27)$ & $26(43)$ & \\
\hline Heterosexual transmission & $23(8)$ & $29(48)$ & \\
\hline Other & $14(5)$ & $5(8)$ & \\
\hline Geographical location in Ontario & & & $<0.01$ \\
\hline Metropolitan Toronto & $112(41)$ & $11(21)$ & \\
\hline Central & $27(10)$ & $9(17)$ & \\
\hline Eastern & $57(21)$ & $11(21)$ & \\
\hline Southwestern & $33(12)$ & $4(8)$ & \\
\hline Northern & $39(14)$ & $17(32)$ & \\
\hline Other & $2(1)$ & $1(2)$ & \\
\hline Employment status & & & $<0.01$ \\
\hline Employed full- or part-time & $87(39)$ & $6(13)$ & \\
\hline Student & $5(2)$ & $1(2)$ & \\
\hline Retired & $13(6)$ & $2(4)$ & \\
\hline Disability & $96(43)$ & $25(54)$ & \\
\hline Unemployed & $23(10)$ & $12(26)$ & \\
\hline Missing data & $66(23)$ & $14(23)$ & \\
\hline Highest education level & & & $<0.001$ \\
\hline Some high school & $48(21)$ & $25(53)$ & \\
\hline Completed high school & $41(18)$ & $8(17)$ & \\
\hline Some college/university & $56(25)$ & $7(15)$ & \\
\hline Completed college/university & $63(28)$ & $7(15)$ & \\
\hline Postgraduate education & $16(7)$ & $0(0)$ & \\
\hline Missing & $66(23)$ & $13(22)$ & \\
\hline Marital status & & & 0.59 \\
\hline Married, living common-law & $88(39)$ & $16(34)$ & \\
\hline Separated/divorced & $14(6)$ & $3(6)$ & \\
\hline Widowed & $6(3)$ & $3(6)$ & \\
\hline Single & $116(52)$ & $25(53)$ & \\
\hline Missing & $66(23)$ & $13(22)$ & \\
\hline Household income/year, \$ & & & 0.02 \\
\hline$<20,000$ & $80(39)$ & $24(62)$ & \\
\hline 20,000 to $<40,000$ & $32(16)$ & $9(23)$ & \\
\hline 40,000 to $<60,000$ & $25(12)$ & $3(8)$ & \\
\hline 60,000 to $<80,000$ & $22(11)$ & $2(5)$ & \\
\hline 80,000 to $<100,000$ & $20(10)$ & $0(0)$ & \\
\hline$\geq 100,000$ & $25(12)$ & $1(3)$ & \\
\hline Missing & $86(30)$ & $21(35)$ & \\
\hline Hepatitis B coinfection & $28(10)$ & $4(7)$ & 0.46 \\
\hline Hepatitis $\mathrm{C}$ coinfection & $69(24)$ & $25(42)$ & $<0.01$ \\
\hline
\end{tabular}

Data presented as $n$ (\%) unless otherwise indicated. IDU Injection drug use; MSM Men who have sex with men

participants being included in the $\mathrm{CD}^{+}$count analysis. For the first late HIV diagnosis definition, $5.1 \%$ of female Aboriginal participants and $5.2 \%$ of male Aboriginal participants were diagnosed with an ADI within three months of HIV diagnosis $(\mathrm{P}=0.98)$. For the second late HIV diagnosis definition, 35\% of female Aboriginal participants and $35 \%$ of male Aboriginal participants had $\mathrm{CD}^{+}$counts $<200$ cells $/ \mathrm{mL}$ at the time of diagnosis $(\mathrm{P}=0.99)$. Median $\mathrm{CD}^{+}{ }^{+}$counts at time of HIV diagnosis for male and female Aboriginal participants were 395 cells $/ \mathrm{mL}$ (IQR 86 cells/mL to 542 cells/mL) and 294 cells/mL (IQR 117 cells/mL to 480 cells $/ \mathrm{mL})$, respectively $(\mathrm{P}=0.69)$.
TABLE 3

Logistic regression model of onset of an AIDS defining illness within three months of HIV diagnosis and a CD4 ${ }^{+}$ count $<\mathbf{2 0 0}$ cells $/ \mathrm{mL}$ at the time of HIV diagnosis

\begin{tabular}{|c|c|c|c|c|}
\hline \multirow[b]{2}{*}{ Covariate } & \multicolumn{2}{|c|}{$\begin{array}{l}\text { Onset of and AIDS defining } \\
\text { illness within three months } \\
\text { of HIV diagnosis ( } n=4572 \text { ) }\end{array}$} & \multicolumn{2}{|c|}{$\begin{array}{l}\mathrm{CD}^{+} \text {count }<200 \text { cells } / \mathrm{mL} \\
\text { at time of HIV diagnosis } \\
(n=1740)\end{array}$} \\
\hline & Unadjusted & Adjusted & Unadjusted & Adjusted \\
\hline Aboriginal & $\begin{array}{c}0.81(0.50- \\
1.33)\end{array}$ & $\begin{array}{c}0.89(0.54- \\
1.47)\end{array}$ & $\begin{array}{c}1.31(0.88- \\
1.96)\end{array}$ & $\begin{array}{c}1.55(1.03- \\
2.35)\end{array}$ \\
\hline $\begin{array}{l}\text { Age (per } \\
10 \text { years) }\end{array}$ & $\begin{array}{c}1.17(1.04- \\
1.32)\end{array}$ & $\begin{array}{c}1.17(1.04- \\
1.32)\end{array}$ & $\begin{array}{c}1.30(1.17- \\
1.43)\end{array}$ & $\begin{array}{c}1.34(1.21- \\
1.48)\end{array}$ \\
\hline Male sex & $\begin{array}{c}1.00(0.70- \\
1.44)\end{array}$ & & $\begin{array}{c}0.87(0.66- \\
1.16)\end{array}$ & \\
\hline \multicolumn{5}{|l|}{ HIV risk factor } \\
\hline MSM & 1 & 1 & 1 & 1 \\
\hline $\begin{array}{l}\text { IDU/MSM- } \\
\text { IDU }\end{array}$ & $\begin{array}{c}0.62(0.39- \\
0.97)\end{array}$ & $\begin{array}{c}0.65(0.41- \\
1.03)\end{array}$ & $\begin{array}{c}0.93(0.66- \\
1.31)\end{array}$ & $\begin{array}{c}0.94(0.66- \\
1.33)\end{array}$ \\
\hline $\begin{array}{l}\text { Heterosexual } \\
\text { transmission }\end{array}$ & $\begin{array}{c}1.96(1.42- \\
2.72)\end{array}$ & $\begin{array}{c}2.03(1.47- \\
2.82)\end{array}$ & $\begin{array}{c}1.83(1.35- \\
2.48)\end{array}$ & $\begin{array}{c}1.81(1.33- \\
2.46)\end{array}$ \\
\hline HIV-endemic & $\begin{array}{c}1.10(0.71- \\
1.71)\end{array}$ & $\begin{array}{c}1.20(0.77- \\
1.88)\end{array}$ & $\begin{array}{l}1.85(1.32- \\
2.59)\end{array}$ & $\begin{array}{c}2.24(1.58- \\
3.16)\end{array}$ \\
\hline Other & $\begin{array}{c}0.79(0.43- \\
1.43)\end{array}$ & $\begin{array}{c}0.79(0.43- \\
1.44)\end{array}$ & $\begin{array}{c}1.58(0.96- \\
2.61)\end{array}$ & $\begin{array}{c}1.44(0.87- \\
2.40)\end{array}$ \\
\hline Toronto & $\begin{array}{c}0.82(0.64- \\
1.05)\end{array}$ & & $\begin{array}{c}0.77(0.62- \\
0.95)\end{array}$ & \\
\hline $\begin{array}{l}\text { Hepatitis B } \\
\text { coinfection }\end{array}$ & $\begin{array}{c}1.26(0.88- \\
1.82)\end{array}$ & & $\begin{array}{c}1.27(0.90- \\
1.79)\end{array}$ & \\
\hline $\begin{array}{l}\text { Hepatitis C } \\
\text { coinfection }\end{array}$ & $\begin{array}{c}0.65(0.45- \\
0.94)\end{array}$ & & $\begin{array}{c}0.65(0.47- \\
0.91)\end{array}$ & \\
\hline
\end{tabular}

Data presented as OR $(95 \% \mathrm{Cl})$. Employment status, education and household income were not included in the model because more than one-half of the data on these variables were missing. IDU Injection drug use; MSM Men who have sex with men

In unadjusted logistic regression models, male sex was not associated with either late diagnosis of HIV as defined according to timing of ADI (OR 1.02 [95\% CI 0.29 to 3.63]; $\mathrm{P}=0.98$ ) or according to $\mathrm{CD}^{+}$count $<200$ cells/mL (OR 1.00, [95\% CI, 0.37, 2.76]; $\mathrm{P}=0.99$ ) (Table 4). Logistic regression models, after adjusting for other covariates, showed no significant effect of sex on either definition of late HIV diagnosis.

\section{DISCUSSION}

In the present study, APHAs were more likely to have a $\mathrm{CD}^{+}$count $<200$ cells $/ \mathrm{mL}$ at the time of HIV diagnosis than non-APHAs, suggesting potential late diagnosis within the Aboriginal population. However, data from these analyses failed to demonstrate a difference in late HIV diagnosis as defined according to ADI between Aboriginal and non-Aboriginal participants. The discrepancy in these findings may suggest that $\mathrm{CD}^{+}$count is a more sensitive marker for late HIV diagnosis. Also, in populations where access to care is an issue, including diagnosis of HIV, the diagnosis of ADIs may also be limited.

Significant differences in demographic and socioeconomic factors existed between Aboriginal and non-Aboriginal participants, and between male and female Aboriginal participants. Aboriginal participants were more likely to have lower levels of income, education and employment than non-Aboriginal participants. Other studies have also found APHAs to have lower socioeconomic status than non-APHAs $(2,23)$, and identified poverty as a barrrier to treatment uptake (24). Similarly, Aboriginal female participants were more likely to have lower levels of income, education and employment than male Aboriginal participants. It is imperative to address these gross discrepancies in socioeconomic factors and the structural factors that make certain populations, such as Aboriginal women, more vulnerable to poorer health outcomes. 
Although female Aboriginal participants tended to have higher $\mathrm{CD}^{+}{ }^{+}$counts at HIV diagnosis and shorter durations from HIV diagnosis to ART start than male Aboriginal participants, these differences were not statistically significant, due at least, in part, to the small numbers of Aboriginal participants and, as a result, low statistical power. In a Vietnamese study, male sex was associated with delayed HIV diagnosis (25). A Canadian study found that among Aboriginal people living off reserve, female sex was associated with an increased likelihood of undergoing an HIV test within the previous year (26). These trends may reflect the impact of prenatal HIV testing because pregnant women may be more likely to be diagnosed at an earlier stage of disease. However, female Aboriginal participants involved in the present study were significantly less likely to have ever been on ART, and this finding is concerning in the context of the prevention of vertical transmission of HIV. The data on ART use were limited in the present analysis, and additional analyses should take duration of ART, indications for ART initiation and reasons for discontinuation into consideration. In addition, female Aboriginal participants were nearly twice as likely to be hepatitis $\mathrm{C}$ coinfected than male Aboriginal participants. This likely represents differences in the rates of IDU and highlights the importance of prevention efforts targeted at addressing the structural, social and historical factors that place Aboriginal women at risk of HIV and hepatitis C.

The findings from the present study have significant policy implications. They call attention to the need for interventions to increase HIV testing uptake among Aboriginal populations. A combination of public health and community-driven programs are needed to help make HIV testing more accessible and acceptable among Aboriginal populations, and to reduce barriers to testing, such as HIV-related stigma. Physicians should be more proactive in offering HIV counselling and testing, coupled with primary prevention efforts, to at-risk populations. Strategies that could lead to more timely HIV diagnoses include professional development and training for physicians and allied health care workers $(27,28)$, as well as increasing access to alternative or newer HIV testing services such as anonymous $(29,30)$, rapid point-of-care (31-33), home-based $(34,35)$ or mobile (36) testing. The goal for increasing HIV testing in Aboriginal populations is to enable earlier diagnoses, which would lead to this population accessing care and ART at higher $\mathrm{CD}^{+}$counts and preventing ADIs. In addition, improving testing and diagnosis of HIV can also have prevention implications. Individuals diagnosed with HIV can be presented with information that will help them to reduce the risk of HIV transmission and HIV superinfection. Initiating individuals on ART may also have a role in the reduction of HIV transmission (37).

Our study has several limitations, one of which was the small sample size of Aboriginal participants. Despite over-representation in the Canadian and Ontario HIV epidemic, Aboriginal peoples are under-represented in the OCS, accounting for only $7.5 \%$ of all OCS participants. Over the past decade, Aboriginal peoples have comprised approximately $20 \%$ of new HIV-positive test results annually in Canada (1). Another limitation is that the OCS only recruits from primary and tertiary health care sites and, thus, only individuals receiving HIV care are included in the study. The individuals who are most at risk for late HIV diagnosis and poor quality of HIV care are likely those who are not accessing services at all and, as a result, are not captured in the study cohort. Because many AHPAs are not receiving care, this cohort fails to include some of the most vulnerable AHPAs in Ontario. This limitation leads to a likely underestimate of the true difference in the proportion of late HIV diagnosis in APHAs versus non-APHAs. In addition, the study participants may not accurately represent the geographical distribution of Aboriginal peoples in Ontario. Recruitment methods that focus on increasing the number of Aboriginal participants in the OCS are greatly needed and the OCS has included Aboriginal participants as a priority population for future recruitment efforts. Strategies could include expanding recruitment sites to community agencies and traditional healers, increasing the
TABLE 4

Unadjusted logistic regression model of onset of an AIDS defining illness within three months of HIV diagnosis and a CD4 ${ }^{+}$count $<200$ cells $/ \mathrm{mL}$ at time of HIV diagnosis among Aboriginal participants

\begin{tabular}{|c|c|c|}
\hline Covariate & $\begin{array}{l}\text { Onset of an AIDS- } \\
\text { defining illness within } \\
\text { three months of HIV } \\
\text { diagnosis ( } n=290 \text { men, } \\
59 \text { women) }\end{array}$ & $\begin{array}{c}\text { CD4 }^{+} \text {count }<200 \text { cells } \\
\text { mL at time of HIV } \\
\text { diagnosis ( } n=94 \text { men, } \\
20 \text { women) }\end{array}$ \\
\hline Male sex & $1.02(0.29-3.63)$ & $1.00(0.37-2.76)$ \\
\hline Age (per 10 years) & $1.51(0.90-2.53)$ & $1.25(0.87-1.79)$ \\
\hline \multicolumn{3}{|l|}{ HIV risk factor: } \\
\hline MSM & 1 & \\
\hline IDU/MSM-IDU & $0.75(0.22-2.48)$ & $0.99(0.38-2.58)$ \\
\hline $\begin{array}{l}\text { Heterosexual } \\
\text { transmission }\end{array}$ & $1.13(0.29-4.33)$ & $1.00(0.35-2.88)$ \\
\hline HIV-endemic & - & - \\
\hline Other & $2.17(0.43-10.87)$ & $1.24(0.19-8.00)$ \\
\hline Toronto & $0.44(0.14-1.38)$ & $1.33(0.59-2.98)$ \\
\hline Hepatitis B coinfection & $0.57(0.07-4.42)$ & $0.34(0.07-1.62)$ \\
\hline Hepatitis C coinfection & $0.78(0.25-2.42)$ & $0.64(0.23-1.79)$ \\
\hline
\end{tabular}

Data presented as OR (95\% CI). IDU Injection drug use; MSM Men who have sex with men

number of recruitment sites in northern Ontario and involving Aboriginal peoples as research team members to advise on recruitment strategies for Aboriginal peoples. Aboriginal peoples and community leaders should be engaged as key partners in all research efforts involving Aboriginal peoples.

Another limitation was that less than one-half of all participants had a documented $\mathrm{CD} 4^{+}$count within six months of HIV diagnosis. Many participants are enrolled in the OCS through tertiary care clinics that do not usually have a complete history of $\mathrm{CD}^{+}{ }^{+}$counts dating back to the time of HIV diagnosis, and this likely contributed to the missing data. The missing data limited the power of our analyses and also may have introduced a respondent bias to the sample. Factors associated with having no documented $\mathrm{CD}^{+}{ }^{+}$count within six months of HIV diagnosis include history of an $\mathrm{ADI}$, hepatitis $\mathrm{C}$ coinfection, receiving disability support and low income. In addition, data regarding employment, education and income were only available for participants enrolled after 2007 , and it was not possible to adequately adjust for these factors in multivariate logistic regression analysis of the participants with a documented $\mathrm{CD}^{+}$count within six months of HIV diagnosis. These missing data represent a significant limitation, because a previous study (38) found low educational level to be associated with late diagnosis of HIV.

Our study was a preliminary analysis and found significant differences in the late diagnosis of HIV between Aboriginal and nonAboriginal OCS participants when late diagnosis was defined according to $\mathrm{CD}^{+}{ }^{+}$count $<200$ cells $/ \mathrm{mL}$ at diagnosis. However, numerous study limitations have been noted. Data limitations can be addressed by targeted recruitment of APHAs, and Aboriginal women living with HIV in particular, in cohorts such as the OCS. Furthermore, the present analysis should be repeated using Canada-wide data, and efforts should be made to collect data on APHAs who are not receiving appropriate health care or for transient populations of Aboriginal peoples who are not often captured in longitudinal cohort studies. More research is also needed on the context of HIV diagnosis and ART among Aboriginal women. Finally, the present study highlights some of the many socioeconomic inequities between APHAs and non-APHAs, and between Aboriginal women and men living with HIV. Future research efforts should address the link between socioeconomic factors and vulnerability to HIV and hepatitis C among Aboriginal peoples. 
ACKNOWLEDGEMENTS: The OHTN Cohort Study (Principal Investigator, Dr Sean B Rourke) is supported by the AIDS Bureau Ontario Ministry of Health and Long-Term Care. Data collection sites and members of the Scientific Steering Committee include: Drs Irving Salit and Janet Raboud (Toronto General Hospital, Toronto, Ontario); Dr Ahmed Bayoumi (St Michael's Hospital, Toronto, Ontario); Drs Mona Loutfy, Graham Smith, Tony Antoniou and Fred Crouzat (Maple Leaf Medical Clinic, Toronto, Ontario); Dr Anita Rachlis, Dr Nicole Mittmann (Sunnybrook Health Sciences Centre, Toronto, Ontario); Dr Wendy Wobeser (Kingston General Hospital, Kingston, Ontario); Dr John Cairney (McMaster University and Centre for Addiction and Mental Health, Hamilton, Ontario); Dr Liviana Calzavara (University of Toronto, Toronto, Ontario); Dr Curtis Cooper (University of Ottawa, Ottawa, Ontario); Dr Marek Smieja (McMaster University, Hamilton, Ontario); Dr Ken Logue (St Clair Medical Associates, Toronto, Ontario); Dr Don Kilby (University of Ottawa Health Services, Ottawa, Ontario); Dr Anurag Markenday (St Joseph's Health Care, London, Ontario); Dr Roger Sandre (Sudbury Regional Hospital, Sudbury, Ontario); and Dr Jeff Cohen (Windsor Regional Hospital HIV Care Program, Windsor, Ontario). We gratefully acknowledge all of the people living with HIV who volunteered

\section{REFERENCES}

1. Public Health Agency of Canada. HIV/AIDS Epi Updates, November 2007. Ottawa: Surveillance and Risk Assessment Division, Centre for Infectious Disease Prevention and Control, Public Health Agency of Canada, 2007:47-58.

2. Heath KV, Comelisse PG, Strathdee SA, et al. HIV-associated risk factors among young Canadian Aboriginal and non-Aboriginal men who have sex with men. Int J STD AIDS 1999;10:582-7.

3. Craib KJP, Spittal PM, Wood E, et al. Risk factors for elevated HIV incidence among Aboriginal injection drug users in Vancouver. CMAJ 2003;168:19-24.

4. Shah BR, Gunraj N, Hux JE. Markers of access to and quality of primary care for Aboriginal people in Ontario, Canada. Am J Public Health 2003;93:798-802.

5. Booth GL, Fang J, Hux JE, Chan BTB. Time trends and geographic disparities in acute complications of diabetes in Ontario, Canada. Diabetes Care 2005;28:1045-50.

6. Pong RW, Pitblado JR. Geographic distribution of physicians in Canada: Beyond how many and where. Ottawa: Canadian Institute for Health Information, 2005:viii

7. Smylie J. A guide for health professionals working with Aboriginal peoples. Journal SOGC 2001;100:1-11.

8. Jackson R, Reimer G. Canadian Aboriginal People Living with HIV/AIDS. Care, Treatment and Support Issues. Canadian Aboriginal AIDS Network. Revised 2008.

9. Lanoy E, Mary-Krause M, Tattevin P, et al. Frequency, determinants and consequences of delayed access to care for HIV infection in France. Antivir Ther 2007;12:89-96.

10. Chadborn TR, Delpech VC, Sabin CA, Sinka K, Evans BG. The late diagnosis and consequent short-term mortality of HIVinfected heterosexuals (England and Wales, 2000-2004). AIDS 2006;20:2371-9.

11. Krentz HB, Auld MC, Gill MJ. The high cost of medical care for patients who present late (CD4 $<200$ cells/microL) with HIV infection. HIV Med 2004;5:93-8.

12. Cohen MS, Chen YQ, McCauley M, et al. Prevention of HIV-1 infection with early antiretroviral therapy. N Engl J Med 2011;365:493-505.

13. Wood E, Milloy MJ, Montaner JS. HIV treatment as prevention among injection drug users. Curr Opin HIV AIDS 2012;7:151-6.

14. Mayben JK, Kramer JR, Kallen MA, Franzini L, Lairson DR, Giordano TP. Predictors of delayed HIV diagnosis in a recently diagnosed cohort. AIDS Patient Care STDS 2007;21:195-204.

15. Schwarcz S, Hsu L, Dilley JW, Loeb L, Nelson K, Boyd S. Late diagnosis of HIV infection: Trends, prevalence, and characteristics of persons whose HIV diagnosis occurred within 12 months of developing AIDS. J Acquir Immune Defic Syndr 2006;43:491-4.

16. Delpierre C, Dray-Spira R, Cuzin L, et al. Correlates of late HIV diagnosis: implications for testing policy. Int J STD AIDS 2007;18:312-7.

17. McDonald AM, Li Y, Dore GJ, Ree H, Kaldor JM. Late HIV presentation among AIDS cases in Australia, 1992-2001. Aust N Z J Public Health 2003;27:608-13. to participate in the OHTN Cohort Study and the work and support of the inaugural OCS Governance Committee: Darien Taylor (Chair), Dr Evan Collins, Dr Greg Robinson, Shari Margolese, Patrick Cupido, Tony Di Pede, Rick Kennedy, Michael Hamilton, Ken King, Brian Finch, Lori Stoltz, Dr Ahmed Bayoumi, Dr Clemon George and Dr Curtis Cooper. The authors thank all the interviewers, data collectors, research associates and coordinators, nurses, and physicians who provided support for data collection and extraction. The authors thank the OHTN staff and their teams for data management and IT support (Mark Fisher, Director, Data Systems) and OCS management and coordination (Virginia Waring, Project Manager, OCS). The viral load data in the OCS was supplemented through a linkage with the viral load database of the Ontario Agency for Health Protection and Promotion. Three investigators are also the recipients of salary support from the Ontario HIV Treatment Network (JR) and the Canadian Institutes of Health Research (MRL, SR). Two investigators have been recipients of research funding from the Ontario HIV Treatment Network (MRL, DJ). SR is the Scientific and Executive Director of the OHTN and receives salary support from this agency. Part of this work was completed during the Comprehensive Research Experience for Medical Students of the Faculty of Medicine, University of Toronto.

18. Wardman D, Quantz D, Clement K. HIV/AIDS: Testing and risk behaviors among British Columbia's rural Aboriginal population. Int J Circumpolar Health 2006;65:313-21.

19. Bucharski D, Reutter LL, Olgilvie LD. "You need to know where we're coming from": Canadian Aboriginal women's perspectives on culturally appropriate HIV counseling and testing. Health Care Women Int 2006;27:723-47.

20. Plitt SS, Mihalicz D, Singh AE, Jayaraman G, Houston S, Lee BE. Time to testing and accessing care among a population of newly diagnosed patients with HIV with a high proportion of Canadian Aboriginals, 1998-2003. AIDS Patient Care STDS 2009;23:93-9.

21. Miller CL, Spittal PM, Wood E, et al. Inadequacies in antiretroviral therapy use among Aboriginal and other Canadian populations. AIDS Care 2006;18:968-76.

22. King SM and the Motherisk-HIV Network Members. Antiretroviral therapy (ART) in a cohort of HIV-positive pregnant women in Canada. Can J Infect Dis 2001;12:26B.

23. Lima VD, Kretz P, Palepu A, et al. Aboriginal status is a prognostic factor for mortality among antiretroviral naïve HIV-positive individuals first initiating HAART. AIDS Res Ther 2006;3:14.

24. Newman CE, Bonar M, Greville HS, et al. Barriers and incentives to HIV treatment uptake among Aboriginal people in Western Australia. AIDS 2007;21:S13-7.

25. Nhac-Vu HT, Giard M, Phong ND, Vanhems P. Risk factors for delayed HIV diagnosis at the hospital of tropical diseases in Ho Chi Minh City, Vietnam. Int J STD AIDS 2010;21:802-5.

26. Orchard TR, Druyts E, McInnes CW, et al. Factors behind HIV testing practices among Canadian Aboriginal peoples living off-reserve. AIDS Care 2010;22:324-31.

27. Hsieh YH, Jung JJ, Shahan JB, et al. Emergency medicine resident attitudes and perceptions of HIV testing before and after a focused training program and testing implementation. Acad Emerg Med 2009;16:1165-73.

28. Krakower D, Kwan CK, Yassa DS, Colvin RA. iAIDS: HIV-related internet resources for the practicing clinician. Clin Infect Dis 2010;51:813-22.

29. Mahendradhata Y, Ahmad RA, Kusuma TA, et al. Voluntary counselling and testing uptake and HIV prevalence among tuberculosis patients in Jogjakarta, Indonesia. Trans R Soc Trop Med Hyg 2008;102:1003-10.

30. Bindman AB, Osmond D, Hecht FM, et al. Multistate evaluation of anonymous HIV testing and access to medical care. Multistate Evaluation of Surveillance of HIV (MESH) Study Group. JAMA 1998;280:1416-20.

31. Guenter D, Greer J, Barbara A, et al. Rapid point-of-care HIV testing in community-based anonymous testing program: A valuable alternative to conventional testing. AIDS Patient Care STDS 2008;22:195-204.

32. Appiah LT, Havers F, Gibson J, et al. Efficacy and acceptability of rapid, point-of-care HIV testing in two clinical settings in Ghana. AIDS Patient Care STDS 2009;23:365-9. 
33. Roberts KJ, Grusky O, Swanson AN. Outcomes of blood and oral fluid rapid HIV testing: A literature review, 2000-2006. AIDS Patient Care STDS 2007;21:621-37.

34. Tumwesigye E, Wana G, Kasasa S, et al. High uptake of homebased, district-wide, HIV counseling and testing in Uganda. AIDS Patient Care STDS 2010;24:735-41.

35. Matovu JK, Makumbi FE. Expanding access to voluntary HIV counselling and testing in sub-Saharan Africa: Alternative approaches for improving uptake, 2001-2007. Trop Med Int Health 2007;12:1315-22.
36. van Schaik N, Kranzer K, Wood R, Bekker LG. Earlier HIV diagnosis - are mobile services the answer? S Afr Med J 2010;100:671-4.

37. Donnell D, Baeten JM, Kiarie J, et al. Heterosexual HIV-1 transmission after initiation of antiretroviral therapy: A prospective cohort analysis. Lancet 2010;375:2092-8.

38. Sobrino-Vegas P, García-San Miguel L, Caro-Murillo AM, et al. Delayed diagnosis of HIV infection in a multicenter cohort: Prevalence, risk factors, response to HAART and impact on mortality. Curr HIV Res 2009;7:224-30. 


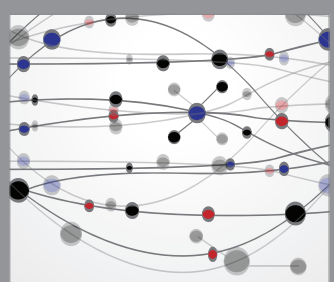

The Scientific World Journal
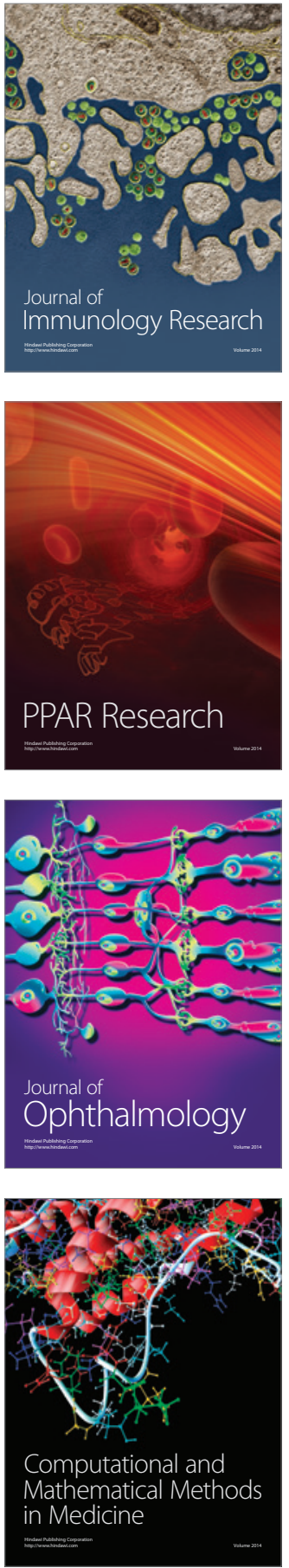

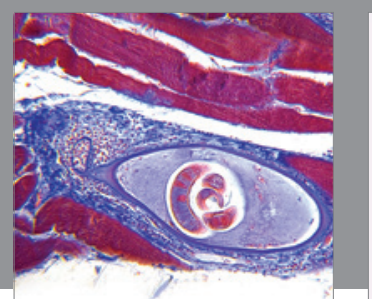

Gastroenterology Research and Practice

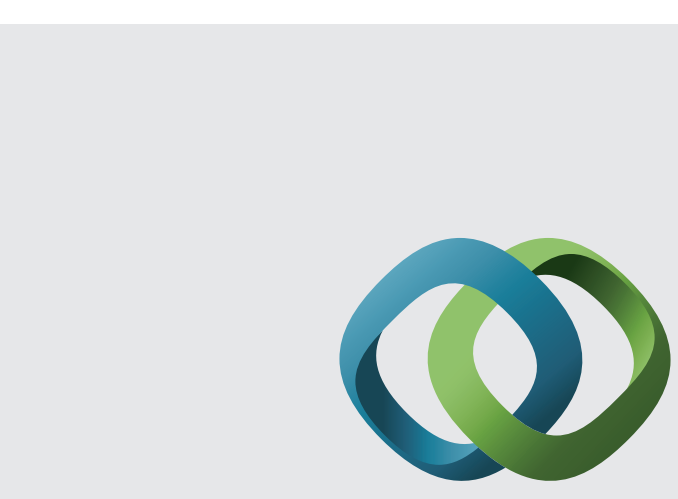

\section{Hindawi}

Submit your manuscripts at

http://www.hindawi.com
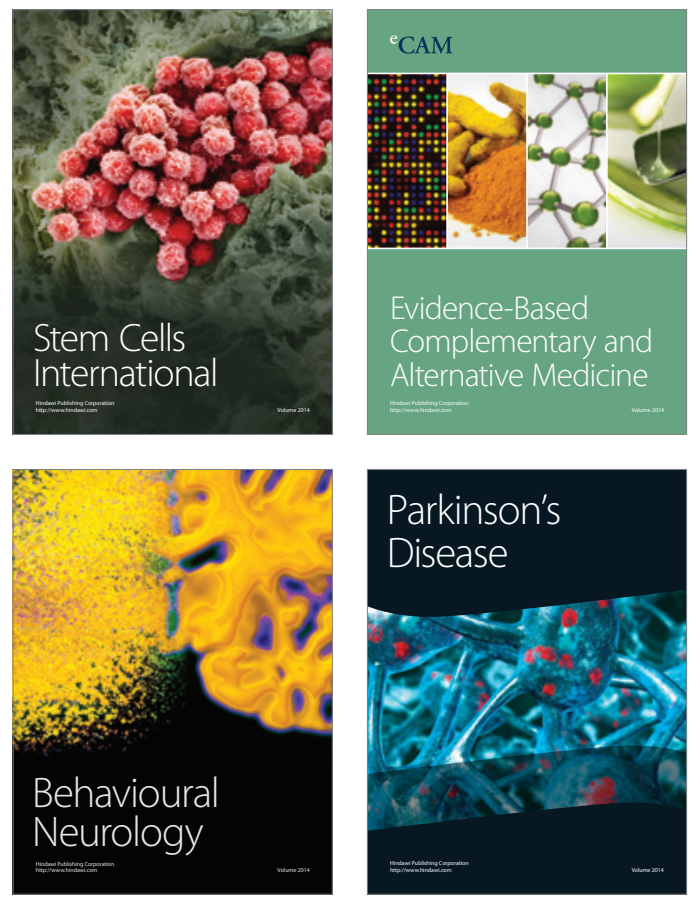
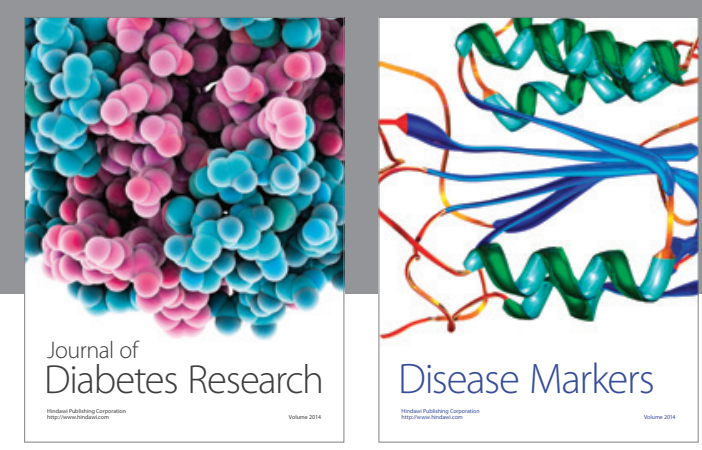

Disease Markers
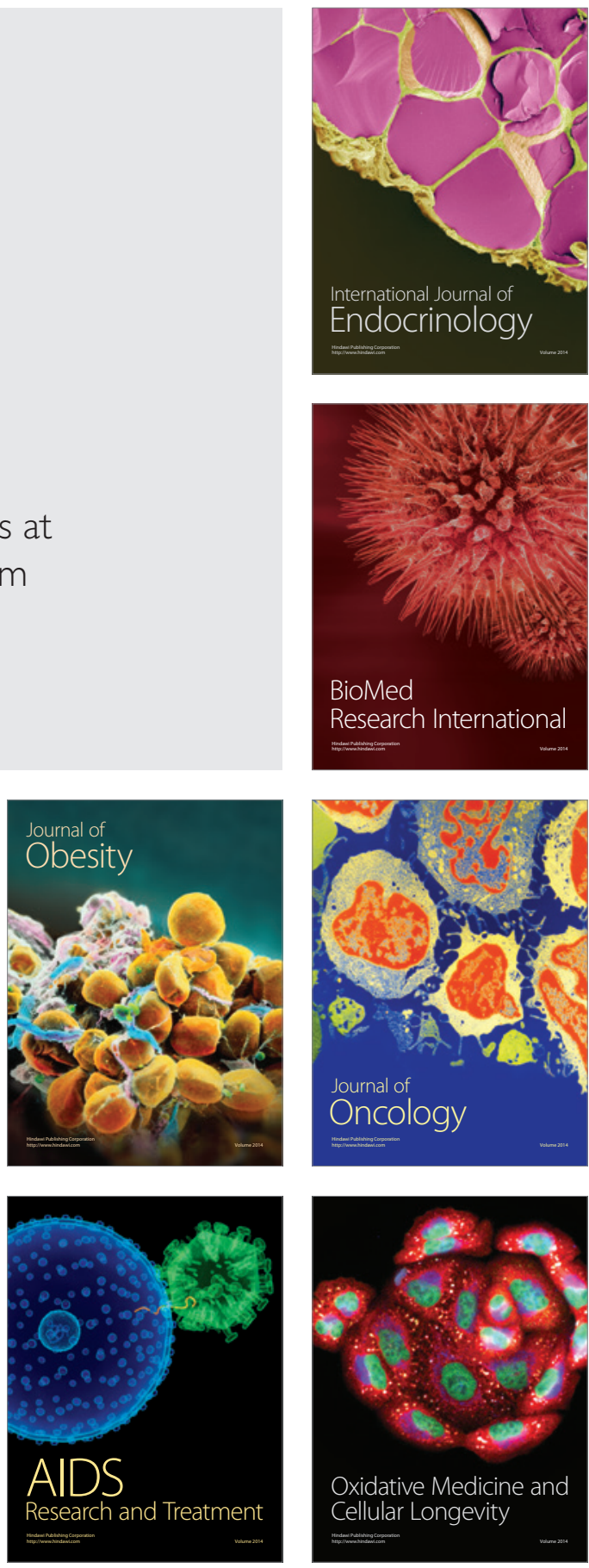